\title{
Comparison of Lassa fever prevention practices between public and private primary health care facilities in Jos, Plateau state, Nigeria
}

Daboer JC' ${ }^{1}$, Sodipo OY', Okoro L², Maimagani $\mathrm{IC}^{2}$, Dogo $\mathrm{JM}^{2}$, Ahgu O², Tagurum YO ${ }^{1}$, Banwat $\mathrm{ME}^{1}$, Aksou $\mathrm{TJ}^{1}$, Chingle $\mathrm{MP}^{1}$ and Zoakah $\mathrm{AI}^{1}$

${ }^{1}$ Department of Community Medicine, College of Health Sciences, University of Jos;

${ }^{2}$ Department of Community Medicine, Jos University Teaching Hospital.

Correspondence: Daboer JC. Email: jonathandabor@yahoo.co.uk

\begin{abstract}
Background: Lassa fever is endemic in Nigeria and health care workers are at a high risk of contracting and transmitting the infection. This study compares Lassa fever prevention practices among health care providers in public and private Primary Health Care facilities in Jos.

Methods: The study used a comparative cross-sectional design to study health care workers in 29 Primary Health Care facilities selected using a two-stage sampling technique. All health care workers who attended to patients were interviewed using a semistructured intervieweradministered questionnaire. Data were analysed using Statistical Package for Social Sciences version 23 and a p-value of $\leq 0.5$ was considered statistically significant.

Results: Majority of the respondents had neither received on-the-job training on Lassa fever prevention (91.9\%) nor Universal Standard Precautions (88.7\%). Private Primary Health Care facilities had better supplies and equipment for Lassa fever prevention compared to their public counterparts. Majority (65.8\%) of respondents had poor Lassa fever prevention practices and this was worse in the private $(75.4 \%)$ than the public (55.6\%) facilities. No facility met all the requirements for Lassa fever prevention. Training had a statistically significant association with good practice among public Primary Health Care facilities.

Conclusion: Noncompliance with Lassa fever prevention practice is still common in Primary Health Care facilities. This is worse in private facilities. Continuous training and improved supplies of materials and equipment are necessary for effective Lassa fever prevention among these health care providers.
\end{abstract}

Key words: Lassa fever, prevention, Primary Health Care, public, private

\section{Introduction}

Lassa Fever (LF) is an acute Viral Haemorrhagic Illness (VHI) that occurs in West Africa. It is responsible for an estimated 300,000-500,000 infections annually, with 5,000 deaths. The disease is endemic in Benin Republic, Ghana,
Guinea, Liberia, Mali, Sierra Leone and Nigeria with Case-Fatality Rate (CFR) of $1 \%$ which can be as high as $15 \%$ among patients hospitalized with severe cases of the disease. Between January and October 2018, there were 548 confirmed cases of LF and 141 deaths (CFR 25.7\%) in 
Nigeria. Twenty two states in the country recorded at least one confirmed case across ninety Local Government Areas (LGAs) which was an increase from the 17 states which were affected in 2017. In the 2018 outbreak, 41 Health Care Workers (HCWs) were affected in 7 states, with Ebonyi and Edo states recording the highest number of 16 and 15 cases respectively. Out of these affected HCWs, 10 deaths were recorded. ${ }^{3}$

The incidence of LF infections among HCWs have involved those who managed individuals with febrile illnesses as well as confirmed cases of $\mathrm{LF}^{4}$ Currently no vaccine is available for $L F$ prevention. Therefore, the hallmark of LF prevention rests on avoiding contact with the host species, vectors and body fluids of humans infected with the virus. In the healthcare setting, these prevention efforts are guided by the National Guidelines on Infection Prevention and Control (IPC) of Viral Haemorrhagic Fevers. ${ }^{4}$ These guidelines also include Universal Standard Precautions (USP). ${ }^{4,5}$ For LF prevention to be effective, HCWs need to adhere strictly to USP and the materials and equipment must be made readily available all the time. ${ }^{4,6}$

Primary Health Care is the foundation of the health care system in Nigeria and the first point of contact between the population and the health care system. With the large clientele attended to at this level, the introduction of any infection with the high potential for spread like LF will have dire public health impact. In the same way, effective infection control measures implemented at this level will protect both the health workers and members of the public from public health catastrophes. Currently the PHC system in Nigeria is characterised by poor staffing, inadequate equipment, poor infrastructure with attendant poor quality of health services when compared to secondary and tertiary levels of care. ${ }^{7,8}$ Some studies have also suggested that differences exist between the quality of healthcare provided by private and public PHC facilities. ${ }^{8,9}$ This study therefore, set out to assess and compare the practices of LF prevention in public and private PHC facilities in Jos metropolis. The gaps identified, if any, will inform the development and/or modification of interventions and strategies to strengthen infection control measures in the PHC setting especially as they relate to LF prevention in Jos metropolis, Plateau state.

\section{Methods}

The study was conducted in Jos metropolis which consists of parts of Jos North and Jos South LGAs of Plateau State. Jos North LGA has an estimated total population of $429,300,10$ with a total of 55 PHC facilities, 34 of which are public and 21 private. Jos South LGA has an estimated total population of 318,943 with a total of 58 PHC facilities; 41 are public and 17 private.10 The study population consisted of public and private PHC facilities in Jos North and Jos South LGAs and their HCWs who come in contact with patients and or their body fluids in the course of their routine clinical duties. The materials and equipment in the PHC facilities were also assessed.

The study used a comparative crosssectional design to study prevention practices of HCWs in public and private PHC facilities and HCWs were selected using a two-stage sampling technique. In the first stage proportionate allocation was carried out to determine the number of public and private PHC facilities to be sampled from the total number of public and private PHC facilities in Jos North and Jos South LGAs. Facilities were selected 
from four sampling frames (one private, one public from Jos North and Jos South respectively) by balloting. To cover at least $25 \%$ of the health facilities in an area when assessing quality of care ${ }^{11-13} 19(25 \%)$ of the 75 total Public PHC facilities in Jos North and Jos South LGAs were selected. Out of these, 9 were proportionately allocated to Jos North and 10 to Jos South LGAs. Similarly $10(25 \%)$ of total private PHC facilities in Jos North and Jos South LGAs were selected. Five each were then proportionately allocated to Jos North and Jos South LGAs. Therefore, the total PHC facilities sampled for study was 29 .

In the second stage, in each selected facility one health worker from each cadre (doctor, nurse, CHO, CHEW, laboratory technician and attendant) on duty at the time of the interview was interviewed. Where there were more than one $\mathrm{HCW}$ of the same cadre in a health facility, the most senior of them involved in clinical work was interviewed. A structured intervieweradministered questionnaire was used to interview the HCWs and a checklist was used to assess the availability and functionality of materials and equipment for LF prevention. These were adapted from the WHO Service Availability and Readiness Assessment (SARA) tool, the Nigerian Centre for Disease Control (NCDC) National Guidelines on Prevention and Control of Viral Haemorrhagic Fevers and the WHO Practical Guidelines for Infection Control in Health Care Facilities. ${ }^{4,5,13}$ The study instruments were administered by trained resident doctors from the Department of Community Medicine, Jos University Teaching Hospital (JUTH), Jos in June and July 2018. Data was coded and entered into the International Business Machine (IBM) Statistical Package for Social Science (SPSS) version 23.0 for analysis.14 Appropriate test statistics were applied and $p \leq 0.05$ was considered statistically significant at $95 \%$ confidence interval.

For availability and functionality of materials and equipment, a score of 1 was assigned for available and functional and 0 for available but not functional and not available. A 3-point Likert scale with scores of 2, 1 and 0 for always, occasionally and never responses respectively were used to score practice. A score of $75 \%$ or more of the maximum score was considered good practice while a score of less than $75 \%$ was regarded as poor practice. Ethical approval for the study was obtained from the Plateau State Ministry of Health Research Ethics Committee. Permission for the study was obtained from the Chairmen of Jos North and Jos South LGAs as well as the medical directors in charge of the selected private PHC facilities. Informed verbal consent was also obtained from all study participants before the commencement of data collection while strict confidentiality was observed in data collection and handling.

\section{Results}

The mean age of respondents was $45.4 \pm 9.2$ years and $41.3 \pm 9.7$ years for public and private PHC facilities respectively. Majority $(72.1 \%)$ were females out of which $84.7 \%$ were married and $79.3 \%$ had completed tertiary education. Over half $(55.9 \%)$ had less than 15 years work experience, while majority had neither received on the job training for LF $(91.9 \%)$ nor on USP $(88.3 \%)$. (Table 1). All the private PHC facilities had latex hand gloves, while only $57.9 \%$ of public PHC facilities had latex hand gloves. Majority of private facilities had face masks $(90.0 \%)$, goggles $(60.0 \%)$, boots $(70.0 \%)$ and autoclave (90.0\%) compared to public PHC facilities where only $31.6 \%, 15.8 \%$, $26.3 \%$ and $15.8 \%$ had face masks, goggles, 
boots and autoclave respectively and the differences in availability of these items between the public and private $\mathrm{PHC}$ facilities were statistically significant $(\mathrm{p}<$ $0.05)$. Only 3 PHC facilities had an incinerator, all of which were privately owned. Only $41.4 \%$ of PHC facilities had an autoclave and majority were in private facilities. No facility had all IPC requirements for Lassa fever (Table 2).

Majority (65.8\%) of respondents' practices of Lassa fever prevention were poor. The poor practices were found more in private PHC facilities (75.4\%). Only 44.4\% respondents in public and $24.6 \%$ in private PHC facilities had good practice of Lassa fever prevention. The difference in practice between private and public facilities was statistically significant $(\mathrm{p}=$ 0.027). (Table 3 ). In public PHC facilities, majority of respondents with good LF prevention practice were $\geq 30$ years of age $(87.5 \%)$, female $(70.8 \%)$, married $(83.3 \%)$ and had tertiary education $(70.8 \%)$. There was, however, no statistically significant association between these factors and practice of LF prevention ( $p>0.05)$. The two largest cadres among respondents with good practice were Nurses $(25 \%)$ and CHEWs (25\%). Six (25\%) of respondents with good practice and $3.3 \%$ of those with poor practice had training on LF prevention. Training had a statistically significant association with practice of LF prevention $(\mathrm{p}=0.019)$. However, $6.7 \%$ of respondents with good practice and $20.8 \%$ of those with poor practice had training on USP. There was no statistically significant association between training on USP and LF prevention practice $(p=0.124)$. (Table 4)

In private $\mathrm{PHC}$ facilities, most $(92.9 \%)$ respondents with good LF practice were $\geq 30$ years of age. All respondents with good practice were married and marital status was significantly associated with the practice of LF prevention $(p=0.047)$. Majority of respondents with good practice had tertiary education $(78.6 \%)$ just like the majority with poor practice (83.7\%). The single largest Cadre among respondents with good practice was the laboratory technicians $(25.6 \%)$ while the single largest group among respondents with poor practice was the CHEWs $(35.7 \%)$. Most (97.7\%) of the respondents with poor practice never had training on LF prevention but this was not statistically significant. With the exception of marital status, no other socio demographic factor was significantly associated with practice of LF prevention ( $p>0.05)$. (Table 5) 
Table 1: Socio-demographic characteristics of respondents in public and private facilities

\begin{tabular}{|c|c|c|c|c|c|}
\hline Variable $(n=111)$ & $\begin{array}{l}\text { Public } \\
\text { Freq. (\%) }\end{array}$ & $\begin{array}{r}\text { Private } \\
\text { Freq. (\%) }\end{array}$ & Total & $\chi^{2}$ & p-value \\
\hline \multicolumn{6}{|l|}{ Age (years) } \\
\hline$<30$ & $5 \quad(9.3)$ & $12(21.1)$ & $17(15.3)$ & \multirow[t]{3}{*}{2.974} & \multirow[t]{3}{*}{0.085} \\
\hline$=30$ & $49(90.7)$ & 45 (78.9) & 94 (84.7) & & \\
\hline Mean age & $45.4 \pm 9.2$ & $41.3 \pm 9.7$ & & & \\
\hline \multicolumn{6}{|l|}{ Sex } \\
\hline Female & $42(77.8)$ & $38(66.7)$ & $80(72.1)$ & \multirow[t]{2}{*}{1.701} & \multirow[t]{2}{*}{0.192} \\
\hline Male & $12(22.2)$ & $19(33.3)$ & $31(27.9)$ & & \\
\hline \multicolumn{6}{|l|}{ Marital status } \\
\hline Single & $7(13.0)$ & $10(17.5)$ & $17(15.3)$ & \multirow[t]{2}{*}{0.449} & \multirow[t]{2}{*}{0.503} \\
\hline Married & $47(87.0)$ & $47(82.5)$ & $94(84.7)$ & & \\
\hline \multicolumn{6}{|l|}{ Educational level } \\
\hline Primary & $7(13.0)$ & $5(8.8)$ & $12(10.8)$ & \multirow[t]{3}{*}{0.753} & \multirow[t]{3}{*}{0.686} \\
\hline Secondary & $6(11.1)$ & $5(8.8)$ & $11(9.9)$ & & \\
\hline Tertiary & $41(75.9)$ & $47(82.5)$ & $88(79.3)$ & & \\
\hline \multicolumn{6}{|l|}{ Staff Cadre } \\
\hline Doctor & $4(7.4)$ & $3(5.3)$ & $7(6.3)$ & \multirow[t]{6}{*}{2.251} & \multirow[t]{6}{*}{0.784} \\
\hline Nurse & $10(18.5)$ & $11(19.3)$ & $21(18.9)$ & & \\
\hline $\mathrm{CHO}$ & $2(3.7)$ & $6(10.5)$ & $8(7.2)$ & & \\
\hline CHEW & $16(29.6)$ & $14(24.6)$ & $30(27.0)$ & & \\
\hline Lab technician & $12(22.2)$ & $14(24.6)$ & $26(23.4)$ & & \\
\hline Attendant & $10(18.5)$ & $9(15.8)$ & $19(17.1)$ & & \\
\hline \multicolumn{6}{|l|}{ Years in practice } \\
\hline$<15$ & $27(50.0)$ & $35(61.4)$ & $62(55.9)$ & \multirow[t]{2}{*}{1.462} & \multirow[t]{2}{*}{0.227} \\
\hline$=15$ & $27(50.0)$ & $22(38.6)$ & $49(44.1)$ & & \\
\hline \multicolumn{6}{|l|}{ Training on LF } \\
\hline Yes & $7(13.0)$ & $2(3.5)$ & $9(8.1)$ & \multirow[t]{2}{*}{3.327} & \multirow[t]{2}{*}{0.068} \\
\hline No & $47(87.0)$ & $55(96.5)$ & $102(91.9)$ & & \\
\hline \multicolumn{6}{|l|}{ Training on USP } \\
\hline Yes & $7(13.0)$ & $6(10.5)$ & $13(11.7)$ & \multirow[t]{2}{*}{0.159} & \multirow[t]{2}{*}{0.690} \\
\hline No & $47(87.0)$ & $51(89.5)$ & $98(88.3)$ & & \\
\hline
\end{tabular}


Daboer JC, Sodipo OY, Okoro L, Maimagani IC, Dogo JM, Ahgu O, Tagurum YO, Banwat ME, Aksou TJ, Chingle MP and Zoakah AI

Table 2: Availability and functionality of equipment for Lassa fever prevention $($ Public $=19$, Private $=10)$

\begin{tabular}{|c|c|c|c|c|c|}
\hline \multirow{2}{*}{$\begin{array}{l}n=29 \\
\text { Item available/functional }\end{array}$} & ublic & rivate & \multirow[b]{2}{*}{ Total (\%) } & \multirow[b]{2}{*}{$\mathbf{X}^{2}$} & \multirow[b]{2}{*}{ p-value } \\
\hline & Freq. (\%) & Freq. (\%) & & & \\
\hline \multicolumn{6}{|l|}{ Rubber gloves } \\
\hline Yes & $11(57.9)$ & $10(100.0)$ & $21(72.4)$ & 5.815 & $0.016 *$ \\
\hline No & $8(42.1)$ & $0(0.0)$ & $8(27.6)$ & & \\
\hline \multicolumn{6}{|l|}{ Face mask } \\
\hline Yes & $6(31.6)$ & $9(90.0)$ & $15(51.7)$ & 8.955 & 0.003* \\
\hline No & $13(68.4)$ & $1(10.0)$ & $14(48.3)$ & & \\
\hline \multicolumn{6}{|l|}{ Googles } \\
\hline Yes & $3(15.8)$ & $6(60.0)$ & $9(31.0)$ & 5.983 & $0.024 *$ \\
\hline No & $16(84.2)$ & $4(40.0)$ & $20(69.0)$ & & \\
\hline \multicolumn{6}{|l|}{ Boots } \\
\hline Yes & $5(26.3)$ & $7(70.0)$ & $12(41.4)$ & 5.154 & 0.023* \\
\hline No & $14(73.7)$ & $3(30.0)$ & $17(58.6)$ & & \\
\hline \multicolumn{6}{|l|}{ Autoclave } \\
\hline Yes & $3(15.8)$ & $9(90.0)$ & $12(41.4)$ & 14.875 & $0.000 *$ \\
\hline No & $16(84.2)$ & $1(10.0)$ & $17(58.6)$ & & \\
\hline \multicolumn{6}{|l|}{ Incinerator } \\
\hline Yes & $0(0.0)$ & $3(30.0)$ & $3(10.3)$ & 6.358 & $0.012 *$ \\
\hline No & $19(100.0)$ & $7(70.0)$ & $26(89.7)$ & & \\
\hline
\end{tabular}

*Statistically significant

Table 3: Practice of Lassa fever prevention in Public and Private Facilities

\begin{tabular}{|c|c|c|c|c|c|}
\hline Practice & $\begin{array}{l}\text { Public } \\
\text { Freq.(\%) }\end{array}$ & $\begin{array}{r}\text { Private } \\
\text { Freq. }(\%)\end{array}$ & $\begin{array}{r}\text { Total } \\
\text { Freq. }(\%)\end{array}$ & $x^{2}$ & p-value \\
\hline Good & $24(44.4)$ & $14(24.6)$ & $38(34.2)$ & 4.869 & $0.027^{*}$ \\
\hline Poor & $30(55.6)$ & $43(75.4)$ & $73(65.8)$ & & \\
\hline Total & 54 (48.6) & 57 (51.4) & $111(100)$ & & \\
\hline
\end{tabular}

*Statistically significant 
Table 4: Comparison of socio demographics and Lassa fever prevention practice in Public facilities

\begin{tabular}{|c|c|c|c|c|}
\hline \multirow[b]{2}{*}{ Variables } & \multicolumn{2}{|c|}{ Practice } & \multirow[b]{2}{*}{$\mathbf{X}^{2}$} & \multirow[b]{2}{*}{ p-value } \\
\hline & $\begin{array}{r}\text { Good } \\
\text { Freq. (\%) }\end{array}$ & $\begin{array}{r}\text { Poor } \\
\text { Freq.(\%) }\end{array}$ & & \\
\hline \multicolumn{5}{|l|}{ Age (years) } \\
\hline$<30$ & $3(12.5)$ & $2(6.7)$ & & \\
\hline$=30$ & $21(87.5)$ & $28(93.3)$ & 0.646 & 0.462 \\
\hline \multicolumn{5}{|l|}{ Sex } \\
\hline Female & $17(70.8)$ & $25(83.3)$ & & \\
\hline Male & $7(29.2)$ & $5(16.7)$ & 1.205 & 0.272 \\
\hline \multicolumn{5}{|l|}{ Marital status } \\
\hline Single & $4(16.7)$ & $3(10.0)$ & & \\
\hline Married & $20(83.3)$ & $27(90.0)$ & 0.687 & 0.469 \\
\hline \multicolumn{5}{|c|}{ Educational status } \\
\hline Primary & $4(16.7)$ & $3(10.0)$ & & \\
\hline Secondary & $3(12.5)$ & $3(10.0)$ & & \\
\hline Tertiary & $17(70.8)$ & $24(80.0)$ & 0.680 & 0.712 \\
\hline \multicolumn{5}{|l|}{ Cadre } \\
\hline Doctor & $1(4.2)$ & $3(10.0)$ & & \\
\hline Nurse & $6(25.0)$ & $4(13.3)$ & & \\
\hline $\mathrm{CHO}$ & $1(4.2)$ & $1(3.3)$ & & \\
\hline CHEW & $6(25.0)$ & $10(33.3)$ & & \\
\hline Lab technician & $5(20.8)$ & $7(23.3)$ & & \\
\hline Attendant & $5(20.8)$ & $5(16.7)$ & 2.093 & 0.836 \\
\hline \multicolumn{5}{|c|}{ Years in practice } \\
\hline$<15$ & $15(50.0)$ & $12(50.0)$ & & \\
\hline$=15$ & $15(50.0)$ & $12(50.0)$ & 0.000 & 1.000 \\
\hline \multicolumn{5}{|l|}{ Training on LF } \\
\hline Yes & $6(25.0)$ & $1(3.3)$ & & \\
\hline No & $18(75.0)$ & $29(96.7)$ & 0.036 & $0.019 *$ \\
\hline \multicolumn{5}{|c|}{ Training on USP } \\
\hline Yes & $2(6.7)$ & $5(20.8)$ & & \\
\hline No & $28(93.3)$ & $19(79.2)$ & 0.221 & 0.124 \\
\hline
\end{tabular}

*Statistically significant 
Daboer JC, Sodipo OY, Okoro L, Maimagani IC, Dogo JM, Ahgu O, Tagurum YO, Banwat ME, Aksou TJ, Chingle MP and Zoakah AI

Table 5: Comparison of socio demographics and Lassa fever prevention practice in private facilities

\begin{tabular}{|c|c|c|c|c|}
\hline \multirow[b]{2}{*}{ Variables } & \multicolumn{2}{|c|}{ Practice } & \multirow[b]{2}{*}{$x^{2}$} & \multirow[b]{2}{*}{ p-value } \\
\hline & $\begin{array}{r}\text { Good } \\
\text { Freq. }(\%)\end{array}$ & $\begin{array}{r}\text { Poor } \\
\text { Freq. }(\%)\end{array}$ & & \\
\hline \multicolumn{5}{|l|}{ Age (years) } \\
\hline$<30$ & $1(7.1)$ & $11(25.6)$ & & \\
\hline$=30$ & $13(92.9)$ & $32(74.4)$ & 0.258 & 0.142 \\
\hline \multicolumn{5}{|l|}{ Sex } \\
\hline Female & $26(60.5)$ & $12(85.7)$ & & \\
\hline Male & $17(39.5)$ & $2(14.3)$ & 0.109 & 0.082 \\
\hline \multicolumn{5}{|l|}{ Marital status } \\
\hline Single & $0(0.0)$ & $10(23.3)$ & & \\
\hline Married & $14(100.0)$ & $33(76.7)$ & 0.054 & $0.047 *$ \\
\hline \multicolumn{5}{|c|}{ Educational status } \\
\hline Primary & $1(7.1)$ & $4(9.3)$ & & \\
\hline Secondary & $2(14.3)$ & $3(7.0)$ & & \\
\hline Tertiary & $11(78.6)$ & $36(83.7)$ & 0.733 & 0.693 \\
\hline \multicolumn{5}{|l|}{ Cadre } \\
\hline Doctor & $3(7.0)$ & $0(0.0)$ & & \\
\hline Nurse & $8(18.6)$ & $3(21.4)$ & & \\
\hline $\mathrm{CHO}$ & $5(11.6)$ & $1(7.1)$ & & \\
\hline CHEW & $9(20.9)$ & $5(35.7)$ & & \\
\hline Lab t echnician & $11(25.6)$ & $3(21.4)$ & & \\
\hline Attendant & $7(16.3)$ & $2(14.3)$ & 2.263 & 0.812 \\
\hline \multicolumn{5}{|c|}{ Years in practice } \\
\hline$<15$ & $9(64.3)$ & $26(60.5)$ & & \\
\hline$=15$ & $5(35.7)$ & $17(39.5)$ & 0.065 & 0.799 \\
\hline \multicolumn{5}{|l|}{ Training on LF } \\
\hline Yes & $1(7.1)$ & $1(2.3)$ & & \\
\hline No & $13(92.9)$ & $42(97.7)$ & 0.434 & 0.395 \\
\hline \multicolumn{5}{|c|}{ Training on USP } \\
\hline Yes & $0(0.0)$ & $6(14.0)$ & & \\
\hline No & $14(100.0)$ & $37(86.0)$ & 0.319 & 0.140 \\
\hline
\end{tabular}

*Statistically significant

\section{Discussion}

In spite of the worsening dimensions of LF outbreaks, majority of respondents in this study, especially in the private facilities, had neither received any formal training on Lassa fever prevention nor universal standard precautions. Training for the effective application of infection prevention techniques is critical for LF prevention and control. ${ }^{15,16}$ A study in Ondo
State, Nigeria revealed that less than a quarter of the HCWs studied had received any training on IPC.17 The extant guidelines on Lassa fever control stipulates regular and continuous training of frontline HCWs in Lassa fever prevention because of the primal place of training in improving knowledge and prevention practice. ${ }^{4}$ Training is even more pertinent when the work force is young and 
inexperienced as was the case in this study where over half of the studied HCWs had less than 15 years work experience. Training improves knowledge and compliance with IPC practices and strengthens preparedness of HCWs before a case of disease presents itself to the facility. ${ }^{18,19}$ In India, a high proportion of HCWs who had received appropriate training had good knowledge on Ebola Virus Disease (EVD) ${ }^{20}$ In Lagos Nigeria, resident doctors who received LF training also had their skills and competence improved. $^{21}$

In this study, private PHC facilities had better supplies of Personal Protective equipments (PPEs) and materials for LF prevention than their public counterparts. This is probably attributable to the fact that private $\mathrm{PHC}$ facilities are profit-driven and patient utilization of service is driven by the availability of equipment in the facilities. Private PHC facility owners therefore pay close attention to supplies and equipment. No PHC facility in this study had all the IPC requirements for LF prevention. Less than half of the PHC facilities had an autoclave and majority of these were private facilities. This was similar to the findings in earlier studies in Nigeria. ${ }^{1722}$ The importance of facilities and equipment for infection prevention in the healthcare setting cannot be overstated. Only 3 facilities had an incinerator, all of which were privately owned. By implication, no public PHC facility had an incinerator of its own or access to any shared incinerator. This has dire consequences for medical waste disposal especially in our environment where dump site scavengers abound. In an era of heightened concerns about communicable disease transmission and epidemics, it is disheartening that the provision of this essential equipment is this poor. This will hamper IPC efforts in general and against Lassa fever in particular. ${ }^{23,24}$
Majority of respondents' practice of Lassa fever prevention in this study was poor irrespective of the facility. This poor practice was more profound in private facilities. Among those with good practice of Lassa fever prevention, more respondents worked in public facilities compared to private facilities. This contrasted with findings in other studies, ${ }^{8,17,2528}$ but agreed with those from a study in Lagos where practice was good in both public and private facilities but better in the public facilities. ${ }^{29}$ It also contrasted with what was documented in a Cameroonian study where practice was better in private than public facilities. Poor practice of standard precautions among the health workers was also noted in other studies. ${ }^{8,15,31}$

Poor practice has been identified as a major contributor to the incidents of needle stick injuries and nosocomial infections. ${ }^{19,27,32}$ Studies in Nigeria and India gave lack of training and inadequate facilities as major factors responsible for poor practice. ${ }^{22,33,34}$ Training was found to be better in public than private $\mathrm{PHC}$ facilities. This probably explains why the practice of LF prevention was better in the public PHC facilities. Even though an earlier study among a similar population found the level of training to be poor, it was better than what was found in our study as almost a quarter of respondents in that study had been trained as opposed to the less than $12 \%$ in our study. ${ }^{17}$ In the public PHC facilities, there was no statistically significant association between prevention practice and socio-demographic characteristics. This could be explained by the fact that the generally poor practice among most respondents might have masked any differences in practice between the sociodemographic strata. A similar study in Lagos also found no differences in LF prevention practice across sociodemographic strata. ${ }^{29}$ However, training on LF prevention was associated with good practice. In a similar study, training on 
infection control was also positively associated with the use of hand gloves and hand washing at the last patient contact and this buttresses the importance of training in LF prevention. ${ }^{17}$

In the private facilities however, it was the marital status that influenced the practice of LF prevention as all the married respondents had good practice. It is difficult to explain the association between marital status and LF prevention practice. There are probably other hidden factors underlying marital status which could explain this relationship. In this study, the cadres with the highest proportion with good practice in the public facilities were nurses and CHEWs while it was the laboratory technicians in private facilities that had the largest proportion with good practice. In a similar study in India, the nurses stood out with the best practice. ${ }^{35}$ The public health implication of this study is that LF prevention practice among $\mathrm{HCWs}$ in PHC facilities is still poor. This poor practice is worse in the private facilities although with less training in infection control and prevention have better supplies of PPEs and materials than their public counterparts. The findings explain why LF endemic communities continue to experience annual worsening disease outbreaks. It highlights the urgent need to institute immediate interventions to improve Lassa fever prevention practices among health care workers in PHC facilities.

\section{Conclusions}

None of the PHC facilities had all the IPC materials and equipment for LF prevention. The private PHC facilities had better supplies of materials and equipment for LF prevention and control than their public counterparts. Training and practice of LF prevention were poor in both groups but practice was better in the public PHC facilities. Training in the public PHC facilities was associated with good practice. Government should ensure training, retraining and supervision of HCWs at PHC level on Lassa fever prevention and control in accordance with the National Guidelines. Owners of PHC facilities should provide such facilities with all the required equipment/materials and training to enable them practice infection prevention and control optimally. Public health stakeholders should endeavor to organize periodic education and training of these workers on infection prevention and control for Lassa fever.

\section{References}

1. World Health Organization. Lassa fever: Key facts [Internet]. 2017 [cited 2018 May 20]. Available from: http://www.who.int/en/newsroom/fact-sheets/detail/lassa-fever

2. Government of England. Lassa fever: origins, reservoirs, transmission and guidelines. Public Health England.[Internet]. 2014 [cited 2018 May 20]. p. 812. Available from: https://www.gov.uk/guidance/lassafever-origins-reservoirstransmission-and-guidelines

3. National Centre for Disease Control (NCDC). Lassa fever outbreak in Nigerian Situation report. \{Internet\}. 2018. [cited 2018 May 20]. Available from: http://www.ncdc.gov.ng/

4. National Centre for Disease Control (NCDC). National Guidelines on Infection Prevention and Control of Viral Haemorrhagic Fevers. [Internet]. 2017. [cited 2018 May 20]. Available from: https://www.ncdc.gov.ng/themes/co mmon/docs/protocols/18_15014959 44.pdf

5. World Health Organization. Practical Guidelines for Infection Control in Health Care Facilities Practical Guidelines for Infection Control in Health Care Facilities. [Internet] 2004. [cited 2018 May 20]. Available from: http://www.wpro.who.int/publication 
s/docs/practical_guidelines_infection control.pdf

6. National Primary Health Care Development Agency (NPHCDA). Minimum Standards for Primary Health Care in Nigeria. [Internet]. [cited 2018 May 21]. Available from: http://nphcda.gov.ng/

7. Aregbeshola BS. Primary Health Care in Nigeria : 24 Years after Olikoye Ransome-Kuti's Leadership. Front Public Health. 2017;5:78.

8. Oyekale AS. Assessment of primary health care facilities service readiness in Nigeria. BMC Health Services Research. 2017;112.

9. Obi AI, Abe E, Okojie OH. Assessment of Essential Obstetric Care Services in Health Care Facilities in Benin City, Edo State. IOSR-JDMS. 2013;10(6):339.

10. Plateau State Government. Plateau State Government: Local Government Areas [Internet]. [cited 2018 May 21]. Available from: http://www.plateaustate.gov.ng/page/ jos-north

11. Urassa DP, Carlstedt A, Nystrom L, Massawe SN, Lindmark G. Quality assessment of the antenatal program for anaemia in rural Tanzania. Int $\mathrm{J}$ Qual Heal Care. 2002;14(6):4418.

12. Maine D, Wardlaw TM, Ward VM, McCarthy J, Birnbaum A, Akalin $\mathrm{MZ}$, et al. Guidelines for Monitoring the Availability and Use of Obstetric Services. Geographical. 1997. 1-103 p.

13. Word Health Organization. Service Availability and Readiness Assessment ( SARA ) An annual monitoring system for service delivery Reference Manual. [Internet]. 2015. [cited 2018 May 20]. Available from: http://www.who.int/healthinfo/syste ms/SARA Reference Manual_Full. pdf

14. IBM Corp. IBM SPSS Statistics for
Windows, Version 23.0. Armonk, NY: IBM Corp. 2016.

15. Aigbiremolen AO, Duru CB, Awunor NS, Abejegah C, Abah SO, Asogun AD. Knowledge and application of infectious disease control measures among primary care workers in Nigeria: the Lassa fever example. Int J Basic, Appl Innov Res IJBAIR. 2012;1(4):1229.

16. Tremblay N, Musa E, Cooper C, Bergh R Van Den, Owiti P, Baller A, et al. Infection prevention and control in health facilities in postEbola Liberia : don't forget the private sector! Public Health Action 2018;7(Suppl 1):110.

17. Ijarotimi IT, Ilesanmi OS, Aderinwale A, Abiodun-Adewusi O, Okon I. Knowledge of Lassa fever and use of infection prevention and control facilities among health care workers during Lassa fever outbreak in Ondo State, Nigeria. Pan African Med Journal 2018. 2018;8688:113.

18. Lee SS, Park SJ, Chung MJ, Lee JH, Kang HJ. Improved Hand Hygiene Compliance is Associated with the Change of Perception toward Hand Hygiene among Medical Personnel. Infect Chemother. 2014; 46(3):16571.

19. Luo Y, He GP, Zhou JW, Luo Y. Factors impacting compliance with standard precautions in nursing, China. Int J Infect Dis. 2010;14(12):e110614.

20. Vailaya CGR, Kumar S, Moideen S. Ebola Virus Disease : Knowledge, Attitude, Practices of Health Care Professionals in a Tertiary Care Hospital. J Pub Heal Med Res. 2014;2(2):138.

21. Adeomi AA, Adeoye OA, Adefemi AK. Perception of senior resident doctors in $\mathrm{N}$ igeria about lassa fever. American Journal of Preventive Medicine and Public Health 2017;1(1):2734.

22. Onowhakpor AO, Adam VY, Sakpa 
OE, Ozokwelu LU. Status of Ebola Virus Disease (EVD) preventive practices among Health care workers (HCWs) in Benin City: a year after disease containment in Nigeria. Pan Afr Med J. 2018;30:50.

23. World Health Organization. Health worker Ebola infections in Guinea, Liberia and Sierra Leone. A preliminary report. 2015;(5):116. Available from: http://www.who.int/csr/disease/ebola /en

24. Hageman JC. Infection prevention and control for Ebola in health care settingsWest Africa and United States. MMWR Suppl. 2016;65(Suppl 4-11).

25. Tobin EA, Asogun DA, Isah EC, Ugege OG, Ebhodaghe P. Assessment of knowledge and attitude towards Lassa fever among Primary care providers in an endemic suburban community of Edo state : implications for control. J Med Med Sci. 2013;4:3118.

26. Lakhani A, Mahmood H, Laeeq A, Mansoor S, Lodhi S, Majid S, et al. Viral hemorrhagic fever in Pakistan: Awareness among health care personnel. J Pak Med Assoc. 2002;52(5):2147.

27. Sadoh WE, Fawole AO, Sadoh AE, Oladimeji AO, Sotiloye OS.

Practice of Universal Precautions among Healthcare Workers. J Natl Med Assoc. 2006; 98(5):7226.

28. Adebayo D, Nwobi EA, Vincent T, Gonzalez J. Response Preparedness to Viral Hemorrhagic Fever in Nigeria : Risk Perception, Attitude towards Lassa fever Epidemiology : Open Access. 2015;5(3).

29. Idris BJ, Inem V, Balogun M. Supplement article Comparing the knowledge, attitude and practices of health care workers in public and private primary care facilities in Lagos State on Ebola virus disease. Pan Afr Med J. 2015;22(Suppl 1) 19:58.

30. Chimfutumba NJA, Anchang YK, Ongore D, Lambert N. Infection Prevention and Control Practices in Public Health Facilities Compared to the Confessional and Private Ones.Science Journal of Public Health 2015; 3(6):86572.

31. Vaz K, Mcgrowder D, AlexanderLindon R, Gordon L, Brown P, Irving R. Knowledge, awareness and compliance with universal precautions among health workers at the University Hospital of the West Indies, Jamaica. Int J Occup Environ Med. 2010;1(4):17181.

32. Bidira K, Woldie M, Nemera G. Prevalence and predictors of needle stick injury among nurses in public hospitals of Jimma Zone, South West Ethiopia. Int J Nurs Midwifer. 2014;6(7):906.

33. Suchitra JB, Lakshmi DN. Impact of education on the knowledge, attitudes and practices among various categories of health care workers on nosocomial infections. Indian Journal of Medical Microbiology 2007;25(3):181-187.

34. Brisibe SFA, Ordinioha B, Gbeneolol PK. Knowledge, attitude and infection control practices of two tertiary hospitals in Port Harcourt, Nigeria. Nigerian Journal of Clinical Practice 2014;17(6):6915.

35. Vaziri S, Najafi F, Miri F, Jalalvandi F, Almasi A. Practice of standard precautions among health care workers in a large teaching hospital. Indian J Med Sci. 2008;62(7):2924. 